\title{
Evidence-based impact by clinical engineers on global patients outcomes
}

\author{
Yadin David ${ }^{1} \cdot$ Thomas Judd $^{2}$
}

Received: 12 February 2019 / Accepted: 14 June 2019 /Published online: 2 July 2019

(C) IUPESM and Springer-Verlag GmbH Germany, part of Springer Nature 2019

\begin{abstract}
The intersection of technological changes and societal evolution has transformed every aspect of human life. Technological advancements are transforming how healthcare knowledge is expanding and accelerating the outreach of critical medical services delivery (Jamal et al. in Health Information Management Journal 38(3):26-37, 2009). While this transformation facilitates new opportunities simultaneously it also introduces challenges (Jacobzone and Oxley, 2001). Appropriate Health Technology (HT) is vital to new and existing global health care programs. Therefore, qualified professionals who can safely guide the development, evaluation, installation, integration, performance assurance, and risk mitigation of HT must be in position to lead. Trained Clinical Engineers (CE) and Biomedical Engineers (BE) have been recognized by the World Health Organization (WHO) as the essential practitioners to providing this critically needed guidance. Over the past four years, a senior professional group participated in an international project that seeks evidence for the hypothesis - that the engagement of CE and BE in guiding HT impacts positively on patient outcomes, while the alternative is that there is no difference. The group collected published data that was subjected to peer review screening; additional data qualification conditions are described in this paper. The project was initiated at the Global CE Summit during the first International Clinical Engineering and Health Technology Management Congress (ICEHTMC) in Hangzhou, China in October 2015 (Global Clinical Engineering Summit at the First International Clinical Engineering and Health Technology Management Congress, 2015). Following the adoption of a resolution to investigate $\mathrm{CE}$ contributions to the improvement of world health status, an international survey and literature survey were initiated. During the first two years of this project 150 case studies from 90 countries were identified covering the previous ten years. The results of this survey were presented to health leaders at the World Health Organization (WHO) World Health Assembly in 2016. Last year, 250 case studies were added including 35 more countries covering the 2016-2017 period. The combined project contains 400 qualified submissions from 125 countries. The conclusion was that engagement of $\mathrm{CE}$ and BME is critical for successful investment in HT and for achieving intended patient outcomes. This paper describes the project's plan, the results of the literature review performed, and the evidence identified during the process.
\end{abstract}

Keywords Healthcare $\cdot$ Clinical engineering $\cdot$ Technology $\cdot$ Management $\cdot$ Safety $\cdot$ Efficacy $\cdot$ Outcomes $\cdot$ Innovation $\cdot$ Success stories $\cdot$ Patient $\cdot$ Life cycle $\cdot$ Access $\cdot$ Quality $\cdot$ System $\cdot$ Device $\cdot$ Global

This article is part of the topical collection on Global Issues in Clinical Engineering

Yadin David

David@biomedeng.com

Thomas Judd

judd.tom@gmail.com

1 Global Clinical Engineering Summit Program Chairman, 1111 Hermann Drive, Suite 12B, Houston, TX 77004, USA

2 IFMBE/Clinical Engineering Division Chairman, 1821 Jacksons Creek point, Marietta, GA 30068, USA

\section{Introduction}

The intersection of technological changes and social evolution has transformed every aspect of human life [1]. This transformation is expansive and most obvious in the changes that has been occurring over the past fifty years in the provisioning of healthcare services [2]. The dependence of health, rehabilitation, and wellness programs on technology for the delivery of services has never been greater [3]. Therefore, it is essential that health technology (HT) be strategically guided and optimally managed [4]. Guidance can only be provided by educated and experienced professionals who can safely lead the 
full life cycle of the technology, starting with innovation and progressing to development, regulatory compliance, evaluation, installation, training, integration, performance assurance, and risk mitigation. However, these professionals must be familiar with the relationship between contributions from HT and their impact on patient outcomes. The understanding of this relationship is a fundamental requirement for achieving optimal return on investment and improvement of outcomes. Such practitioners are critical members of the healthcare team and should be in position to facilitate technology-related plans.

Beyond the ongoing healthcare burdens of population growth, political and economic instability, disease management, disasters, refugees, accidents, terror attacks, and increasing dependence level on technology, our world of healthcare systems is facing enormous challenges to manage its resources in the twenty-first century. The flood of scientific and technological innovation is radically redefining the nature of healthcare in virtually every dimension, from vascular nanoengineered interventions and predictive diagnostic tests to image guided surgery and remote telehealth-based services at the national and global levels. However, most healthcare systems are not adequately staffed to safely and effectively manage these forces of change. Most systems are structured around vertically-expert professions (medical doctors, medical physicists, nurses, administrators), but lack the "horizontal expertise" that trained Biomedical and Clinical Engineers (BE\&CE) provide. For example, the expertise in assessing and managing the integration and the performance of complex smart systems that have varying areas of service, durations of technological lifecycle [5], hardware and software platforms, and middleware in support of integrated medical and surgical services.

Disproving the myth - that there is a lack of evidence to qualify how much the dependency of HT is well-guided by CE expertise and best practice methodology - led to our examination of published literature and formal presentations of case studies in which CEs, BEs, and those in similar roles have participated. This allowed us to answer the question whether their participation contributed to improvement in overall healthcare outcomes. In the field of HT management and $\mathrm{CE}$, the incentives to publish studies are lower than it should be, resulting in limited volume of resources to develop best practice measures. Despite these perceived limitations, our results were recently published [3]. In this paper, the focus is on the process used for the selection of data sources and the methodology to qualify their inclusion, described in the Methodology section of this paper.

On the other hand, over the past 50 years, concerns were expressed that there is a lack of knowledge by Government Agencies and key stakeholders, coupled with limited recognition for those contributions for the practitioners that guide the deployment, creation and safe deployment of health technology. Our data answers these concerns. If the knowledge and the expertise of the global CE community does have a critical role in optimal guidance of HT deployment, how can that expertise be best demonstrated. The collection of the case studies (that were later called success stories) from all over the world can facilitate the determination if there is competency unique to CEs around the world that leads the development and optimal management of these technology life cycles. Having this knowledge can help to reach better understanding of the required strategy to achieve desired patient outcomes when technology is used in care and rehabilitation management.

The Ebola virus disease crisis [6] has demonstrated that multidisciplinary team expertise and collaboration are keys to success. Low resources countries in particular face a challenge of improving their health services because, in addition to the above stated challenges, they also have scarce availability of professional expertise trained to address technology-related issues [7]. Varied availability and state of infrastructure and human resources place higher demand on adequate management of HT innovation and deployment. The effective health workforce of the twenty-first century consists of more individual practitioners caring for complex health-issues and thus charged with deploying the most optimal benefits from medical technology, such as proper selection, effectiveness, timely access, and affordable. In academia, government, and industry, teams of BE\&CE translate design innovations and integrate knowledge of science, engineering, standards and regulations with clinical strategy to create new tools that save and improve lives while building more quality into patient outcomes. In hospitals, $\mathrm{BE} \& \mathrm{CE}$ practitioners ensure that proper acquisition, installation, integration and operation of devices and systems are safe and efficient. With the increasing role of technology in the delivery health care services, professional competency of the entire span of the technology lifecycle across systems and sectors - is critical to achieving the full benefits and best outcomes clinically, economically, and operationally.

\section{Methods}

Following the resolution adopted at the first International Clinical Engineering and Health Technology Management Congress [8] that took place in Hangzhou, China, in October 2015, senior members from the CE profession from around the world who participated in the Global CE Summit [9] initiated the international project seeking evidence to the hypothesis that the engagement of $\mathrm{CE}$ and BE in guiding HT deployment positively impacts patient outcomes while the null hypothesis was that there is no difference. The group identified the volume of published data that and developed criteria for inclusion pertinent and 
qualified publications. The rules are shown in Fig. 1 below. Several conditions were placed on the total volume of publications and formal presentations that were found. Only sources that responded positive to the challenge of the criteria were included in the final examination. To begin with, the source must be subjected to peer-review screening. Secondly, the source must include care-related outcomes in the body of the manuscript, thirdly the source had to be published in IFMBE [10] sponsored publication or event (meeting) proceedings, fourthly, the source must describe how CE or BME practices led to the second criterion of outcomes, and the fifth criterion limit the source inclusion to specific window of time. This window was defined as 2005-2015 for the first phase of this examination, and 2016-2017 for the second phase.
During the first two years of the project 150 case studies from 90 countries were identified and satisfied the criteria described in Fig. 1. Searching through the time span over a period of previous ten years (2005-2015). The results of the initial review were presented to health leaders from member countries at the WHO World Health Assembly in 2016. The interest generated in the project helped to sustain its work and as a result of the continuation of data analysis the team identified and qualified additional 250 case studies from a total of 125 countries covering the period of the 2016-2017. The combined project's two stages examine and qualified over 400 qualified submissions from 125 countries.

Next, we looked at the methodology of putting together peer recognized clinical engineering experts from around the world, all members of the IFMBE clinical engineering
Fig. 1 Selection factors for determining inclusion of data source

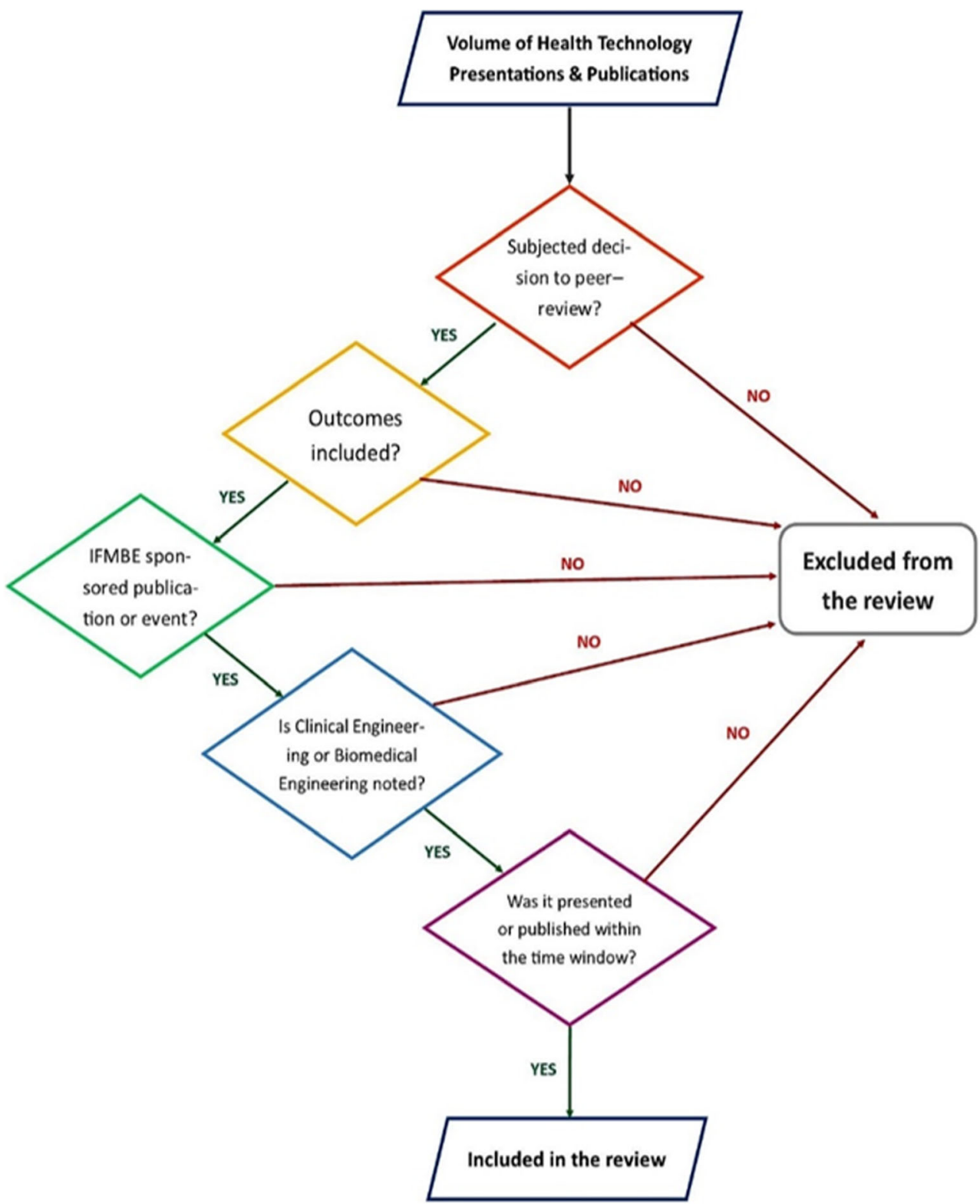


division and issued a call for collections of papers from around the world, that will demonstrate what is the involvement and what is the contribution of individual programs from around the world in the CE arena. Within 6 months, in 2016, we were able to collect a vast volume of evidence that was qualified and filter into 150 specific studies from 90 countries. The literature sources and the results of the examination are presented, grouped into six categories of outcomes impact.

The resulting qualified volume of sources were categories into groups. The six groups were created to facilitate decision if sufficient evidence has been accumulated to support conclusion of outcomes. While the six categories were reviewed independently the significant overall commonality is that they all address different aspects of HT technology's impact on outcomes. Data collected that met the inclusion criteria was grouped into six categories as follows:

\subsection{Innovation}

Through provision of new HT solutions, adaptation of existing, or a combination to address several issues.

\subsection{Access}

Ease in reaching HT-related health services or facilities in terms of location, time, and ease of approach.

\subsection{Health systems}

Positive impact from more efficient and effective deployment of HT at national or policy level.

\subsection{Safety \& Quality}

HT's positive impact on health services safety or quality outcomes, or through HT human resource development.

\subsection{Healthcare technology management (HTM)}

Establishing or improving HTM methodology resulting in improved population health or wellness.

\section{6 e-Technology}

Improvements achieved due to deployment of Internet-based HT tools.Following phases of the technology life cycle the analysis of the data began with the group that starts the cycle - with the innovation phase. Innovation and the provision of new solutions to existing problems. The next group, reasonable progression to health services. Where the question to address was the possible existence of evidence to demonstrate that the access to health care services has increased because of technology management programs. Or, did the HT management program established methodologies that improve the overall finance and/or wellness of the population. After that, review of data was conducted with regard to overall impact on National or regional systems or multi-hospital health systems. Safety and Quality services that dependent on complex technological systems is critical for outcomes and therefore identified with its own group of data Technology management group was the next category to be reviewed where CE/BME contributions to organized, integrate, manage, and improve safe and efficient sustainable HT. Finally, in a way of looking forward the future, the group of e-Technology where telemedicine, image guided interventions, Informatics and disaster response operation were grouped together. Making assumption that with the introduction of complex technological systems improvements in patient care safety and the quality of services receive were evident.

With review of data in these six categories this study was able to cover major activities that are technology-dependent in health. Successful source (or submission) was defined as satisfying objective measures developed by the investigators: timeliness, cost saving, deployment or adoption by care providers, impact on services, and overall projection for success. Each success metric was evaluated using 3-point scale against a statement representing the success construct $(1=$ strongly disagree; $3=$ strongly agree). Timeliness refers to whether the project/submission was implemented in timely manner. This was measure by the statement "The submission will impact outcomes on present time."

The cost measure was evaluated on whether the submission's overall costs were within budget constraints and reasonable for the conditions in the region. This was assessed by the statement, "The submission cost objectives can be met in the region." The final two metrics were combined into the statements "The submission will be deployed by its intended users" and "The submission will have a positive impact on those who will adopt it." Finally, overall submission success was assessed with the statement "All things considered, the submission will be a success." Success was determined when the source received overall rating of 2 or above.

\section{Results}

Sources for data collection included the following: IFMBE/ Clinical Engineering Division (CED) 2016 Health Technologies Resources [11] document provided to the World Health Assembly, WHO in May 2016, the 2nd and 3rd Global Forums on Medical Devices [12] organized by the World Health Organization IFMBE/ CED's China and Brazil ICEHTMC [12] October 2015 and September 2017 respectively, others [13] IFMBE journals proceedings and published sources from the period 2016-2017. The results 
containing criteria inclusive and qualified data were tabulated and categorized into six categories that are described in tables below. The tables provide detailed information about the category of the submission, the region summitted it, the submission title and authors identification. Each of submission is accompanied by hot link facilitating further data and evidence details that the reader is welcome to pursue. The data in these tables with the accompanied links demonstrates that evidence exists for benefit registered in each of the six categories from every region around the world. Overall this review identified evidence from 400 case studies received from 125 countries where management of medical devices (as main component of health technologies) made a positive difference over the past twelve years. The results of first phase of the literature survey were incorporated into a document that in May of 2016 was successfully presented to the world Health Assembly consisting of member country delegations of Ministry of Health from around the world to WHO in Geneva Switzerland [14].

Data collection and analysis was conducted over three years period employing the same selection factors as shown in Fig. 1. The analysis shows that volume of evidence exists in the literature to demonstrate the important and critical contributions of CE and BME to the initiation of new and improvement of present care outcomes. These contributions are evident on every continent and every day of the year. Not just randomly but continuously $24 \times 7 \times 365$ days. After the completion of the two phases of this literature survey 400 publications from 125 countries document evidence and showing the success of Clinical engineering competency serving on the healthcare delivery team (Tables 1, 2, 3, 4, 5 and 6).

The case studies are actually HT Success Stories demonstrating, in a limited resource environment, that it is desirable to include professional HT expertise, such as clinical engineers, in national decision-making in order to maximize health systems' services. Case studies from the links on the following pages demonstrate these benefits:

- Access: The Ministry of Health HT Unit-led project in Albania that doubled access to critical diagnostic services, such as computed tomography scanners, magnetic resonance and angiography imaging, while reducing equipment downtime to zero, and significantly reducing cost.

- Health Systems: Improved coordination between multiple stakeholders in the National Laboratory and its satellites in Colombia, led by the Ministry of Health and clinical engineers who partner with experts from academia and industry.

- Quality \& Safety: A clinical engineer-led 122-hospital program in the Shanghai region that cooperates with officials, industry, and academic entities, resulting in improved device user satisfaction, tracking of emerging technologies, and closer partnerships with industry.
- Table 1 Innovation

- Table 2 Access

- Table 3 Management

- Table 4 Health Systems

- Table 5 e-Technology

- Table 6 Quality \& Safety

In all of the above mentioned topics, data collection, review and validation continued throughout the project period as access to IFMBE sponsored events and related publications was secured in phases. During 2017 and 2018 we added more evidence that was qualified by our criteria. 250 additional stories from additional of 35 countries, were now increasing the overall count to 400 publications from 125 countries. All with evidence, showing the success from CE involvement in the relationship to improving patient outcomes, and the derived benefits from HT creation, management, and deployment. Involvement that is documented through services provided over 365 days a year, $24 \mathrm{~h}$ a day, 7 days a week. To be included in the project evidence database, shown in the tables above, each entry must comply with conditions for inclusion and with performance parameters described earlier of timeliness, costsaving, extent of deployment or adoption by care providers, impact on overall services and estimated projection for the entry success. The timeliness parameter complied if an impact has been described in the entry as immediate as in present tense. Other parameters were similarly considered similarly.

All entries included can be viewed through the on-line links provided in the tables. The hot links to all the resources the task force reviewed and qualified were validated. The tables are color coded to facilitate ease readers interest of seeking additional details for a specific technology category.

Examples of entries from the table above describe details as follow:

In the innovation category, for example, Anne-Louise Smith from Adelaide, Australia, with a team of clinicians identified a need for solution to specific clinical problem related to retrieval to transfusion of fluids of patients who maybe in a shock. No device was able to meet the need of fulfilling the task without external power source. The entry - BME development of non-electric portable blood/fluid warmer for roadside trauma, describe the critical contribution of $\mathrm{CE}$ to create solution, test it, identify and resolve usability barriers and bring it to commercialization. Transferring of patients in rural areas is now safer and having better patient outcomes. The engineering expertise and the collaboration with physicians were key factors for the success evident in this entry.

In the Health Systems category: Bilal Beceren, from Turkey, affiliated with Ministry of Health $(\mathrm{MoH})$ of Turkey practices at the National HT management program, involved 800 public hospitals. Prior to 2013 there was no $\mathrm{MoH}$ based program and knowledge of the medical technology assets deployed. They embarked on national project in 2015 that built 
Table 1 List of Innovation-related submissions organized by region submitting it with authors information and hot links

Focus Area Innovation: Title, authors, with active links

Afghanistan, Iraq, Libya, Occupied Palestinian Territory, Somalia, Sudan, Syria, and Yemen

\section{Australia}

Australia

Australia

Bangladesh

Brazil

Brazil

Brazil

Brazil

Brazil

Brazil

Brazil

Brazil

Brazil

Brazil

Brazil

Canada

Chile

China

Colombia

Colombia

Colombia

Colombia

Colombia

Colombia

Colombia

Colombia

Colombia

Colombia

Croatia

Denmark, Norway

Ethiopia

Global

Global

Global

Global

Global

Global

Global

Global

Global

Global

Global

Global
Medical Devices for Emergency Kits (NCD Kit), Laura Alejandra Velez, Slim Slama

Phototherapy to Reduce Exchange Transfusions, Luciano Moccia, Gaston Arnolda, Daniele FREO2 oxygen solutions: The Low-Pressure Oxygen Storage system and FREO2 Siphon, BME development of non-electric portable blood/fluid warmer for roadside trauma, Anne-Louise Smith, Mark McEwen

Health Technology enhancing rural Primary Care and eHealth, Ahmed Raihan Abir

Dynamical Orthostatic Chair Development of a new method of lifting and locomotion, Walef Robert Ivo Carvalho

A multiband reflectance photometric device for reveal gestational age at birth, Rodney

Prematurity detection by light, Zilma Reis, Rodney Nascimento Guimarães, Gabriela Luíza

Actions travelling ECG for Telemedicine - a partnership of academic and public service, Kleber Teixeira de Souza et al

Flow Analyzer for Blood Pump, L.R. Rodrigo, A.M. Marcelo and S. Anderson

Principal Component Analysis usage in Biomedical Engineering to aid at diagnosing pa, E.F. Esmanhoto

Digital Storage and System Management for Video surgery Records in a Network Plat-, Benedito Fernandes De Lima et al

Early stage strategic effectiveness evaluation of high flow nasal therapy (OPTIFLOW®), Graziela de Araujo Costa et al

Location of electromedical equipment in closed environment using wi-fi technology, William Knob de Souza

Remote Equipment Monitoring System, A. Ricardo Maranho

Model fitting and simulation of the respiratory control system under incremental exer-, C. A. Sarmiento, A. M. Hernández, L. Y. Serna [15]

Provincial Respiratory Outreach Program in the Province of British Columbia (BC), An- thony Chan, Esther Khor

Clinical Simulations using actors as a patients as part of a strategic plan to reduce risks

A novel automatic method of renal segmentation in GRF estimation, Xu Lei

Modeling and simulation of ciprofloxacin pharmacokinetics: Electric circuits approach, J. D.

Otálvaro, A. F. Zuluaga, A. M. Hernández [16]

Autoregressive models of electrocardiographic signal contaminated with motion arti-. A. Castaño, A. M. Hernández [17]

Parametric modeling of kinetic-kinematic polycentric mechanical knee, A. M. Cárdenas, J. Uribe, A. M. Hernández [18]

Motion artifacts recognition in electrocardiographic signals through artificial neural, A. Castaño, A. Hernández [19]

Learning tool for mechanical ventilation during spontaneous breathing test on patients, M. B. Salazar Sánchez et al. [20]

Optimization of spectral analysis of electrophysiological recordings of the subthalamic, S. E. Valderrama-Hincapié et al. [21]

Three dimensional reconstruction and airflow simulation in a realistic model of the hu-, A. E. Ruiz, J. K. Aristizábal [22]

Permanent magnets to enable highly-targeted drug delivery applications: A computa-, M. Mercado-M et al. [23]

Brain functional connectivity in Parkinsons disease - EEG resting analysis, J. Carmona, J. Suarez, J. Ochoa [24]

Business Opportunities in HT Projects, Mario Castañeda

Supporting Diabetic Patients with a Remote Patient Monitoring Systems, S. Zulj et al. [25]

Impedance-based monitoring for tissue engineering applications, C. Canali et al. [26]

Producing Oxygen Concentrators for Low Resource Settings, Mekdes Seyoum

Development of an Innovative regulated Affordable Uterine Balloon Tamponade for the

How we drive innovation within medical devices, Kristoffer Gandrup-Marino, UNICEF

A new handheld cordless thermal coagulator, W. Prendiville, S. Rengaswamy, B. Partha, P. Groesbeck, Wallace Dean, Pickett Tim, Riddle Mike, Juan Felix

Safer medication administration for labor/delivery, Beth Kolko; Bradley Younggren

Enabling and scaling early detection of breast cancer in lmics, Mihir Shah, et al

Ultra-low-cost endoscopy for gastroesophageal cancer screening in low-income coun, et al

Unsupervised electronic stethoscope for childhood pneumonia diagnostic, Mohamed-

Field testing a neonatal phototherapy device: a novel approach, Donna Brezinski, et al

Test for management of preeclampsia, Wendy Davis, et al

Device to save postpartum-hemorrhaging women in advanced shock, M Guha, et al

Validity of a device for jaundice screening, Anne Cc Lee, et al

CE-IT Innovation: How to Make Health Care Right, Mario Castañeda, Tom Judd 
Table 1 (continued)

\begin{tabular}{|c|c|}
\hline Focus Area & Innovation: Title, authors, with active links \\
\hline Global & WHO Priority Medical Devices, Adriana Velazquez Berumen; Gabriela Jimenez Moyao, Anto \\
\hline Global & Appropriate digital X-ray system with eHealth services, Romain Sahli \\
\hline Global & Role of biomedical engineer in assessing medical devices, Leandro Pecchia \\
\hline Global & Challenges in TB Diagnostics, Christopher Gilpin \\
\hline Global & The Digital Health Atlas for Inventories and Routine Registration of Digital Health In \\
\hline Global & Global Cooperation on Assistive Technology: WHO Priority Assistive Products List, \\
\hline Global & Essential Resources for (Emergencies and) emergency care, Teri Reynolds \& Ian Norton \\
\hline Global & The role of biomedical engineers, James Goh \\
\hline Global & Innovative appropriate technologies for low resource settings, Adriana Velazquez \\
\hline Global & Access to medical devices for Universal Health Coverage and SDGs, \\
\hline Global & 2014: WHO medical device list for Ebola care, Adriana Velazquez \\
\hline Global & WHO Technical Specifications for Oxygen Concentrators, 2015, Adriana Velazquez \\
\hline Global & Quick $\$ 2$ test reveals if you caught a superbug in hospital, Hakho Lee, BME MGH, Boston \\
\hline India & GANDHI: global affordable need driven health innovations, Prashant Jha \\
\hline India & Hypothermia alert device: saving newborn lives, Ratul Narain; Gini Morgan \\
\hline India & Novel Technology Policy: Integrating Service Delivery to Industry Promotion, Jitendar \\
\hline India & Preventing apneas of prematurity, Ratul Narain; Gini Morgan \\
\hline India & Remote monitoring for critical infants, Ratul Narain; Gini Morgan \\
\hline India & MoH "Andhra Med Tech Zone" administering new medical devices manufacturing park, \\
\hline India & MoH Innovations project, WHO 2GFMD, Jitendar Sharma, 2013 \\
\hline Italy & Current and Future Trends in the HTA of Medical Devices, Oriana Ciani et al. [27] \\
\hline Italy & HTA of a Large Tablet System in Digital Pathology, Daniele Giansanti et al. [28] \\
\hline Italy & Rapid Clinical Evaluation of Robotic Surgery, Stefano Gidaro \& Luca Radice, 2016 \\
\hline Macedonia, Haiti, China & CED Role in Linking Global HT Innovation and Standards: From the Research Lab to the \\
\hline Malaysia & Biomechanics of Long-Distance Cycling of a Transtibial Amputee, Azman Hamid \\
\hline Mexico & Semi Active Hand Orthosis, R. Itzel Flores-Luna, Ruben Valenzuela-Montes, David De-Jesus- \\
\hline Peru & Heavy-Metals Point of Care Detection HT to improve care, Herb Voigt, Fred Hosea \\
\hline Senegal & Oxygen generators type PSA: solution for the supply of oxygen in Senegal, Awa Ndiaye \\
\hline Senegal & Innovative Diagnostics for Infectious Diseases, Catharina Boehme \\
\hline South Africa & Medical device innovation-Local production of medical devices in Africa: characterizing \\
\hline Tanzania & $\begin{array}{l}\text { Maternal Child Health medical devices: potential impact of disruptive technology in Mbuyita, } \\
\text { Mbaruku, et al., }\end{array}$ \\
\hline Uganda, India & Cross Border Learning: Catalyzing Medical Technology Innovation with LMICs, Alexis \\
\hline UK & Automating the diagnosis of Childhood Pneumonia, Elina Naydenova, Climent Casals- \\
\hline UNICEF & Medical Devices for Maternal, Neonatal and Child Care, Paul LaBarre \\
\hline Uruguay & Clinical Engineering driving new public hospital design \& construction, Franco Simini, 2016 \\
\hline WHO & WHO HT Innovations for Low Resource Countries, Adriana Velazquez \\
\hline
\end{tabular}

information about medical assets purchasing, commissioning and facilitated better performance support. CE training was initiated, and maintenance support has increased. The outcomes show that medical technology has been acquired under better terms, more efficiently maintained, the uptime of $95 \%$ for covered inventory now was reachable facilitating better patient care. Annual audits conducted since show that from unknown level prior to 2013 the program in 2015 reached coverage of $88 \%$ of the inventory in the country. National health technology management system for public hospitals in Turkey improve the performance and cost efficiency of the technology that patient management is dependent upon.

In the Access category: Ledina Picari from the $\mathrm{MoH}$ in Albania, a clinical engineer by training identified concern about the access to diagnostic services. Diagnostic imaging technology was not properly maintained and equipment up time did not meet patients' need. In 2014 a collaborative national project was initiated to examine the state of equipment management and identify opportunities for increasing access to diagnostic services, to increase clinical availability of diagnostic technology at the local level, and to increase efficient and effective use of public funds. The evidence provided shows that in 2015 the volume of CT examinations more than doubled from 3157 to 6602 exams while the equipment downtime was reduced from almost four months a year down to near 0 days. This is important achievement that in addition delivered the benefit of reducing the maintenance costs from about 10 to $12 \%$ before the project was initiated down to $8 \%$ of the purchase price per annum afterwards. Diagnostic technology availability significantly improves patient's outcome.

A second example in the Access to health services category that bridges to e-Technology and specifically a Telemedicine program was initiated with CE guidance (Yadin David) in Houston, Texas. The project aimed at connecting rural community in Central America Village 
Table 2 List of Access-related submissions organized by region submitting it with authors information and hot links

\begin{tabular}{|c|c|}
\hline Focus Area. & Access: Title, authors, with active links \\
\hline Africa & Medical Devices Situation in the Africa Region, Stanislav Kniazkov \\
\hline Albania & HTM improves high technology diagnostics access, Ledina Picari \\
\hline Argentina & HT improving Provincial Access, 2015, German Giles \\
\hline Australia \& Canada & Using Telehealth to improve Diabetes care, E. Sloane, N. Wickramasinghe, S. Goldberg \\
\hline Brazil & Evaluation of production capacity, the healthcare coverage and the access of computer-, Diana Lima et al \\
\hline Brazil & Distribution of mammographs by macro-region of Brazil, Ana Claudia Patrocinio \\
\hline Brazil & The Role of Clinical Engineers for the Management of Healthcare Technologies in a, Eduardo Jorge \\
\hline China & Survey of Prolonged Mechanical Ventilation in Intensive Care Units in Mainland China, Li J et al. [29] \\
\hline Cuba & A Telemedicine System to follow-up the Evolution of Chronic Diseases in the Commu \\
\hline Denmark & The mobile laboratory: bringing high-quality testing, to the patient, Susanne Andresen \\
\hline Global & Market Dynamics: Supporting Country Decision- Making on Medical Devices, Ray \\
\hline Global & Equipment Planning, Safety and Maintenance: Planning of Medical Imaging Services in \\
\hline Global & Surgery: indispensable interventions are not readily available, Walt Johnson \\
\hline Global & International Atomic Energy Agency: Roadmap to Cancer-Free World, Rajiv R Prasad \\
\hline Global & The importance of laboratory and pathology for a good diagnosis and treatment, need \\
\hline Global & The Rise of Telehealth, Yadin David et al \\
\hline Global & Linear Accelerators Case Studies, Marcos Martins \\
\hline India & Prioritisation of medical devices and diagnostics in India, Yogita Kumar, Gupta Madhur, \\
\hline India & Ministry of Health $(\mathrm{MoH})$ Mobile Medical Units, Jitendar Sharma \\
\hline India & MoH Free Diagnostics Service Initiative, Jitendar Sharma \\
\hline India & MoH National Dialysis Program, Jitendar Sharma \\
\hline India & Telemedicine Reducing Blindness in South India, Niranjan Khambete \\
\hline Kenya & Improving Universal Health Coverage Kenya PPP example, Gisela Abbam, Farid Fezoua \\
\hline Mexico & CENETEC - National inventory of high-tech medical equipment as HTM tool for strategy \\
\hline $\begin{array}{l}\text { Mozambique, Tanzania, Malawi, Togo, DR } \\
\text { Congo }\end{array}$ & Global Healthcare Telemedicine, Michelangelo Bartolo \\
\hline Paraguay & Innovative tele-diagnosis technology for universal coverage in remote locations without \\
\hline Romania & Telemonitoring Systems and Technologies for Independent Life of Elderly, S. B. Sebesi [30] \\
\hline Slovakia & $\begin{array}{l}\text { Telemedicine and mHealth System for Complex Management in T1DM and T2DM Pa-, Fedor Lehocki, } \\
\text { Tomas Bacigal [31] }\end{array}$ \\
\hline $\begin{array}{l}\text { Sudan, Egypt, Lebanon, Somalia, } \\
\text { Afghanistan and Iraq }\end{array}$ & Strengthening Health Technologies \& Medical Devices Management in EMRO, Adham \\
\hline Syria & Hemodialysis in Syria: a BME Approach, Lana Almohamad \\
\hline WHO & WHO Cancer Care Initiative 2015-2016, Adriana Velazquez et al \\
\hline
\end{tabular}

of Zacapa, Guatemala, on the edge of the rainforest, with the large medical center in Houston. Without such access to the subspecialty of pediatric dermatologists, the effect of tropical diseases on children there was not attended to. However, with the telemedicine-based technology and medical knowledge a project was facilitated offering proper diagnostic and guidance of local care providers on how to manage these patients. The smile on the children's face afterwards told the whole story.

In the Safety and Quality category, Li Bin, a CE from Shanghai, China, identified the need for having better technology quality control as there was not clear measure in the management of the technology in large network of care providers before 2005. Network of care providers facilities in community of 23 million population, 122 hospitals above grade two, and about $1000 \mathrm{Ce} \& \mathrm{BME}$ in the region. As result of this project in 2016 they changed the conditions from lack of quality standards in purchasing and servicing of diagnostic technology they implemented enhanced management program with collaboration of industry. Data sharing and benchmarking information led to better cooperation between the parties, improve service personnel training, the initiation of annual quality improvement reporting and to sustain readiness of technology to serve clinical objectives. They now know that there are 26 billion yuan of medical equipment assets, this is about 4 billion dollars USD that due to CE management 
Table 3 List of Management-related submissions organized by region submitting it with authors information and hot links

\begin{tabular}{|c|c|}
\hline Focus Area. & Management: Title, authors, with active links \\
\hline $\begin{array}{l}\text { Benin, Burkina Faso, Burundi, } \\
\text { Cameroon, DRC, Ethiopia, } \\
\text { the Gambia, Ghana, Ivory } \\
\text { Coast, Kenya, Nigeria, South Africa, Tanzania, Uganda, } \\
\text { Zambia }\end{array}$ & $\begin{array}{l}\text { THET NGO \& South Africa enhancing } 15 \text { African HTM societies, Anna Worm \& Mladen } \\
\text { Poluta }\end{array}$ \\
\hline Australia & In-house Endoscopy support, 2016, Anne-Louise Smith \\
\hline Bangladesh & Clinical Engineering Approach to Improve Healthcare Technology Management for En- \\
\hline Benin & Evaluation of medical devices in Benin, Charles Pascal Soroheye, Adjaratou Seidou Maliki, \\
\hline Benin & Maintenance management of medical devices in Benin: The case of Papané Hospital, \\
\hline Bhutan & Bhutan Health Technology Management (HTM) and HTA 2015, Tashi Penjore \\
\hline Bosnia \& Herzegovina & $\begin{array}{l}\text { Testing of dialysis machines in healthcare institutions in Bosnia and Herzegovina, Lejla } \\
\text { Gurbeta [32] }\end{array}$ \\
\hline Botswana & Using HTM to improve care delivery, Bonnie Tlhomelang \\
\hline Brazil & Impact of clinical engineering in primary healthcare, Priscila Avelar, Renato Garcia, Carlos \\
\hline Brazil & Logistics of medical devices for indigenous health care attending in remote sites at Bra- \\
\hline Brazil & GETS System on CE-HTM, Jose Bassani \\
\hline Brazil & Medical device manuals analysis using heuristic evaluation, J.C. Carneiro et al \\
\hline Brazil & Proposed Calibration of Apheresis Equipment, A.S. Anderson et al \\
\hline Brazil & Maternal Fetal Simulator, L.R. Rodrigo et al \\
\hline Brazil & Evaluation of Sphygmomanometers: comparison between manual and digital measure- \\
\hline Brazil & Hospital Maintenance Management, A.S. Forte, J.E.Neto \\
\hline Brazil & Study involving X-Ray Tube Life spam in Computed Tomography Equipment, Petrick \\
\hline Brazil & HTA Applied to HTM through Clinical Engineering, Santos F. A. [33] \\
\hline Burkina Faso & The problem of acquisition and maintenance of biomedical equipment in Burkina Faso, \\
\hline Chile & Activities of Clinical Engineering in the University of Valparaiso, Guillermo Avendano \\
\hline Chile & The Chilean Navy Hospitals 15 years of CE, Francisco Acevedo \\
\hline China & Preventive Maintenance of Fetal Monitors, LE He-qing \\
\hline China & $\begin{array}{l}\text { The Survey of } 3 \text { Departments in Guangdong Province Under New Regulations, Yang } \\
\text { Shaozhou }\end{array}$ \\
\hline China & Impact of national CE Certification on Health Technology, Zhou Dan \\
\hline Colombia & $\mathrm{CE}$ and impact on financial management of the hospital, Paula Berrio \\
\hline Colombia & Estimation of the optimal maintenance frequency of medical devices: A Monte Carlo [34] \\
\hline Colombia & $\begin{array}{l}\text { Teaching maintenance of medical devices in simulation centers: a pilot study, Quiroga } \\
\text { Torres D. A. [35] }\end{array}$ \\
\hline Costa Rica & Clinical Engineering - Health Technology Management (HTM) key areas of challenge \\
\hline Costa Rica & HTM in Costa Rica, G Murillo, M. Ingeana \\
\hline Cuba & Cuba Health Technology Management, Jorge Castro Medina \\
\hline Dominica & Health Technology Management in Dominica, R. Williams \\
\hline Ecuador & Development of Biomedical Engineering in the Honorable Junta de Beneficencia of \\
\hline El Salvador & Health Technology Management in El Salvador, Juarez S. \\
\hline Ethiopia & Managing Successful Medical Device Warranty Period Maintenance, Demeru Yeshitla \\
\hline Ethiopia & Strengthening Utility and Maintenance of Medical Devices, Demeru Yeshitla Desta, Sharon \\
\hline Ghana & CMBES HTM Donations Study, 2015, Bradley, Yoon, Zahedi, Adusei-poku, Bill Gentles \\
\hline Global & Medical device ownership models and maintenance contracting approaches, Lisa Smith, \\
\hline Global & $\begin{array}{l}\text { The Missing Link: The Role of BMETs Throughout the HTM Lifecycle, Anna Worm, } \\
\text { THET; }\end{array}$ \\
\hline Global & Global HTM Update 2011, Binseng Wang et al \\
\hline Global & Global HTM Update 2015, T. Judd, S. Calil, A. Hernandez, B. Gentles \\
\hline Global & $\begin{array}{l}\text { IFMBE CED Development of e-Courses for HTM training 2015-2016, Ernesto Iadanza } \\
\text { [36] }\end{array}$ \\
\hline
\end{tabular}


Table 3 (continued)

\begin{tabular}{|c|c|}
\hline Focus Area. & Management: Title, authors, with active links \\
\hline Global & Orbis International Global HTM Training, Ismael Cordero \\
\hline Global & ACCE Global HTM Seminars, 2013 2GFMD, Antonio Hernandez et al \\
\hline Haiti & Using HTM to improve care delivery, Monette Valliere, Jean Chery \\
\hline Italy & Launch of the new WHO Collaborating Centre for Research and Training in CE and HTM, \\
\hline Italy & A Novel Approach to Improve the Technical Maintenance of Biomedical Equipment [37] \\
\hline Jamaica & Health Technology Management in Jamaica, 2010, Keith Richards \\
\hline Kenya & MoH ophthalmic equipment support, Philip Anyango, Mary Nguri \& Joseph Rugut \\
\hline Kenya & MoH Device HydroCarbon Refrigeration Training BMETs, J. Rugut \\
\hline Kosovo & HTM in Kosovo, 2010, Agron Boshnjaku S. Ramiqi S, K. Hashani \\
\hline Kyrgyzstan & HTM in Kyrgyzstan, 2010, Kazbek Agibetov \\
\hline Laos & HTM in Laos, 2GFMD 2013, Thanom Insal \\
\hline Lebanon & HTM Implementation at Saint George Hospital - Lebanon, Riad Farah \\
\hline Lebanon & Medical Devices Repair/Replacement Algorithm Model, Riah Farah \\
\hline Mexico & Decodifying HTM in Mexican Private Hospitals, Luis Fernandez \\
\hline Nigeria & Key areas of challenge and progress of CE-HTM in Nigeria, Bukola Esan \\
\hline Paraguay & Health Technology Management in Paraguay, Pedro Galvan \\
\hline Peru & Fostering Clinical Engineering \& HTM in Developing Countries: Alignment and Effec \\
\hline Puerto Rico & Health Technology Management update in Puerto Rico, Oscar Misla \\
\hline Romania & Prioritization of Medical Devices for Maintenance Decisions, S. Taghjpour et al \\
\hline Rwanda & Medical device technician training, A. Worm, Mpamije Tonkin, Mol, Kasaro \\
\hline Saudi Arabia & Creation of Health Technology Technical E-Library, Salah Alkhallagi \\
\hline Senegal & Maintenance of medical devices and quality management in Senegal, Dr. Mamadou Sow, \\
\hline Sierra Leone & Immediate impacts of inventory on procurement,donations,maintenance and use of \\
\hline South Africa & Math Model for Reliable Maintenance of Medical Equipment, Baset Khalaf, 2015 \\
\hline Sub-Sharan Africa & The status of medical equipment in Sub-Sahara Africa, Anna Worm, Theogene Nama- \\
\hline Sudan & part2 \\
\hline Taiwan & Medical Devices Troubleshooting, KP Lin \\
\hline Taiwan & $\begin{array}{l}\text { The Benefit of In-Hospital Clinical Engineer Services for Medical Devices Maintenance, } \\
\text { [38] }\end{array}$ \\
\hline Taiwan & Taiwan: An IM Strategy for In-House CE Department Based on Equipment Service Life- \\
\hline Tanzania & Health Technology Management in Tanzania, Y Mkwizu \& R Masanja \\
\hline Tanzania, Switzerland & Building management capacities for essential equipment in Tanzania, WHO 2GFMD, \\
\hline The Gambia & Medical Research Council HTM Unit, Anna Kah, Ebrima Nyassi \\
\hline Togo & The governance problem in medical equipment donation projects: Case of Togo, WHO \\
\hline Uganda & Using HT Policy and HTM to improve MoH care delivery, Sitra Mulepo, Kataaha Edward \\
\hline UK & Apprenticeship model for clinical engineering workforce development, Abdul Basit, Mal- \\
\hline USA & Kaiser Permanente Clinical Engineering Staffing Best Practices 2015, Chris Ewing \\
\hline Zambia & $\begin{array}{l}\text { Medical equipment maintenance personnel and training in Zambia; S. Mullally, T. Bbuku, } \\
\text { [39] }\end{array}$ \\
\hline
\end{tabular}

improved outcomes for both financial investment in technology and clinical services to patients.

The e-technology category has another example of how BE \& CE contributed to better outcomes, specifically during the devastating earthquake in Port-au-Prince, Haiti. In that occasion, article of New England Journal of medicine, March 2010, describes how 109 support staff, including CE, arrived at Haiti and within two days after the earthquake, established a field hospital that was able to treat 1100 patients, performed 320 surgeries, and delivered 16 babies. The first baby born there was named by his mother 'Israel'after the group origin that came to establish the field Hospital there.

Finally, in the HT Management category, in Brazilian rainforest, we found another evidence for how CE expertise has helped to achieve better patient outcomes and improving care. Ryan Pinto Ferreira from University of Campinas, 
Table 4 List of Health Systems-related submissions organized by region submitting it with authors information and hot links

Focus Area

Africa

Africa - 18 countries

Albania

Albania

Argentina

Asia Pacific

Bangladesh

Bangladesh

Bosnia and Herzegovina

Brazil

Brazil

Brazil

Brazil

Brazil

Brazil

Brazil

Brazil

Brazil

Brazil

Brazil

Cameroon

Cameroon

Canada

Chile

China

China

Colombia

Colombia

Colombia

Colombia

Colombia

Colombia

Colombia

Cuba

Czech Republic

Ethiopia

EU (28 Member States), EFTA/EEA: Norway, Liechtenstein, Iceland; Turkey; Switzerland

Ghana

Ghana, Canada

Global

Global

Global

Global

Global

Global

Global

Global

Global

Global

Global

Global

Global

Global

Global

Global

Global

Global
Health Systems: Title, authors, with active links

The potential power of sub-Saharan Africa professional associations for biomedical/clinical engineering professionals [40]

The (improved) status of medical equipment in sub-Sahara Africa HTM: A. Worm, L.

Regulation, standards and market surveillance of medical devices and systems in AlbaMoH Health Technology (HT) Unit device legislation, Ledina Picari, 2016

Present and Future of Clinical Engineering in Argentina, German Giles, Marcelo Lencina Status of Biomedical Engineering education in the Asia Pacific, KP Lin et al [41]

Biomedical and clinical engineering development, Md Ashrafuzzaman et al

Necessity of Clinical Engineering to Regulate the Medical Devices in Middle Income Medical devices in legal metrology framework, Lejla Gurbeta, Almir Badnjeviffi Analysis of the Curriculum of Postgraduate Courses in Clinical Engineering in Brazil, AnApplication of multiparameter method as an assistance to the evaluation of the need Assistant Multi-Parametric Method to the Selection in the Process of Incorporation of International Standards for Medical Device and The U.S. Food and Drug Administration, Computed Tomography scanners productivity and examinations times, R.P. Santos et al Defibrillators in locations with a high concentration/movement of people in Bauru/BraFDA Internationalization Under the Aspect of Medical Device Standards, R.G. Fernandes, Medical equipment acquisition methodology in public procurement process, J. Martins Cost Estimate Methodology in procurement processes of Medical Equipment, V. O. Fagundes [42]

Study of Medical Device Purchasing Cycles through Temporal Series Analysis, J. C.

Guerrero [43]

RENEM - MoH HT list driving national investment, Murilo Conto

Development of the National Healthcare Technology Policy for Cameroon, J. Riha Improvement in the use of medical devices and capitalization of investments in the HT Clinical Engineering/HTM in Canada, Mario Ramirez

University of Valpariso Health Technology leadership, Cristian Diaz

Clinical Engineering in China, Bao Jiali, Zhu Chaoyang

HTM as key health planning discipline, Guanxin Gao

Integrated model of universities to promote clinical engineering, Nelson Escobar, Javier Interuniversity model of cooperation for the development of Clinical Engineering in CoMethodology Design for Biomedical Technology Replacement Planning, D. M.

Regional Nodes of Colombian Clinical Engineers, Andrea Garcia Identifying the needs in the integration of disciplines in the hospital infrastructure man [44] HT Regulation, Policy, Management, 2015, Andrea García Ibarra, Rojas Morales Clinical Engineering for non-engineers: acquisition of medical equipment, 2011, Tatiana

Trading barriers in the medical devices industry. Are these barriers hindering the development of this sector in Cuba? [45]

Hospital Based HTA - Implementation for the Czech Republic, Ivana Kubátová, Veronika [46]

Using HT Policy and HTM to improve care delivery, Mulugeta Mideksa, 2015

The Regulation of medical devices in the European Union, Carlo Pettinelli

Clinical Engineering in Ghana, Nicholas Adjabu

CMBES Donations Project, 2015, Nicolas Adjabu, John Zienna, Bill Gentles

IFMBE/CED and Global CE-HTM Evidence Based Results, Yadin David, Ernesto Iadanza

IFMBE/CED Role in Global BME/CE recognition, James Goh, Ernesto Iadanza

Global CE-HTM Success Stories, Yadin David, Tom Judd

Technical characterization of appropriate medical equipment, Maurice Page, Matthieu

MSF medical equipment framework, Gabriela Jimenez Moyao, Oscar Rodriguez, Tom

Lauwaert,

Assessment of medical devices in low-income settings, L. Pecchia, N. Pallikarakis The AHWP Playbook for Implementation of a Health Technology Regulatory FrameGlobal Atlas of Medical Devices, Adriana Velazquez

Medical Devices for universal health coverage and sustainable development, Marie-Paule The Book, Human Resources for Medical Devices, the Role of the Biomedical Engineer, National medical equipment policies and planning for universal health coverage, RobImproving medical equipment donations: contribution of NGO Humatem, Cathy Health Technology Management Initiatives, Ernesto Iadanza

Health Technology Assessment of innovative medical devices, Iñaki Gutiérrez-Ibarluzea IFMBE/Clinical Engineering Division projects for the advancement of the profession of

Clinical Engineering [47]

The importance of Technical Specifications, Adriana Velazquez

The Role of HTM to the Universal Health Coverage, P. Galvan et al

2009 WHO database of biomedical/clinical engineering teaching units and associations 
Table 4 (continued)

\begin{tabular}{|c|c|}
\hline Focus Area & Health Systems: Title, authors, with active links \\
\hline Global & Global HT Disaster Preparedness, Yadin David, Fred Hosea \\
\hline Global & Latin American \& Caribbean Health Technology Training, 2013, Antonio Hernandez \\
\hline Global & Role of IFMBE in medical equipment in developing countries, Worm, Linnenbank [48] \\
\hline Global & The importance of establishing a national policy for infrastructure, Africa Health, Andrei \\
\hline Global & Need for Undergraduate Clinical Engineering Education, 2015, Herb Voigt \\
\hline Global & MAKING IT WORK: Managing medical equipment in low-resource settings video, THET \\
\hline Global & The role of HTM in WHO, to support access to medical devices for Universal Health Cov- \\
\hline Global & IFMBE HTA Division Filling the gap between HTA and HTM, Leandro Pecchia \\
\hline Global & Global Health Technology Equity: How Emerging CE-HTM Leaders Can Help, Antonio \\
\hline Greece & Medical equipment management, Nicolas Pallikarakis, Institute of Biomedical Technology, \\
\hline India & Generic Specifications for Medical Equipment in Developing Countries, S.B.Sinha, \\
\hline India & MoH HTM via Public Private Partnership, 2015, Jitendar Sharma \\
\hline India, Indonesia, Thailand & South East Asia Regional Perspective, Madhur Gupta \\
\hline Indonesia & Development of biomedical engineering education in Indonesia, Cholid Badri \\
\hline Italy & The Italian Clinical Engineers Association: a success story, Stefano Bergamasco, Paolo \\
\hline Italy & $\begin{array}{l}\text { Assessing the impact of a CIS/PACS technology for a cardiology department using QFD } \\
\text { [49] }\end{array}$ \\
\hline Italy & Model national CE society and impact on legislation, Paolo Lago, Lorenzo Leogrande \\
\hline Japan & Roles of Clinical Engineering in medical device development, Hiroki Igeta et al \\
\hline Japan & The Business Operations of CEs, Roles and Certifications, Jun Yoshioka \\
\hline Kenya & Using HTM to improve $\mathrm{MoH}$ care delivery, Philip Anyango Amoko \\
\hline Kyrgyzstan, Albania & HT characteristics of countries in the WHO European region, Tifenn Humbert \\
\hline Latin America & $\begin{array}{l}\text { The status of Biomedical Engineering (BME) programs in Latin America, Martha Zequera } \\
{[50]}\end{array}$ \\
\hline Mexico & Health Technology Project Value Chain, Andrade Bravo Ignacio \\
\hline Mexico & Opportunities of the Mexican Biomedical Engineering Society to influence and adopt \\
\hline Mexico & CENETEC- MoH HT Unit creates nation-wide HTM capacity, Roberto Ayala \\
\hline Mexico & HTA, HT Regulation, HTM to improve care delivery, Cardenas, de Alba, Orencio, Moreno \\
\hline Moldova & Medical Devices Management Strategy in the Republic of Moldova, V. Sontea et al. [51] \\
\hline Nigeria & Using HT Policy and HTM to improve care delivery, Bukola Esan \\
\hline Peru & Improving Emergency Preparedness through Hybrid Interactive Training, T. Clark, R. Ri- \\
\hline Peru & $\begin{array}{l}\text { A Comprehensive System for HTM, L. Vilcahuaman, M. Cordova, J. Kalafatovich, R. Rivas } \\
\text { [52] }\end{array}$ \\
\hline Peru & $\begin{array}{l}\text { MoH \& National Institute of Health HT Unit care improvement strategies, Rossana Rivas, } \\
\text { Luis Vilcahuaman }\end{array}$ \\
\hline Peru & Collaborative HT partnerships to improve care delivery 2015, Rossana Rivas \\
\hline Portugal & Technology decision-making process: MRI purchase in Portugal, Maria Maia \\
\hline Romania & Knowledge about materio-vigilance in Cluj-Napoca, Romania, Simona Maria Mirel \\
\hline Rwanda, Benin, Cam- eroon, Guinea, Nigeria, Sierra Leone & The odyssey of an HTM Expert, Mboule, Cameroon \\
\hline Sierra Leone, Canada & Sierra Leone / Canada: Transnational Donations of Medical Equipment, Dinsie Williams, \\
\hline Singapore & Global BME Education Programs, 2016, Siew-Lok Toh \\
\hline South Africa & Health Technology Management in the African Continent, Mladen Poluta \\
\hline Suriname & Using HTM to improve care delivery, Gillian Jie \\
\hline Taiwan & Intern programs of biomedical engineering education, Kangping Lin; Tsai, Chenglun \\
\hline Taiwan & BME/Clinical Engineering (CE) Role for Policy Implementation of Medical Equipment re \\
\hline Taiwan & Accreditation of BME/CE in Taiwan, KP Lin \\
\hline Turkey & $\begin{array}{l}\text { MoH HT Unit product tracking/surveillance/pricing \& Country-wide HTM Data, Ugur } \\
\text { Cunedioglu, Bilal Beceren }\end{array}$ \\
\hline Turkey & HTM improving country-wide care delivery, Bilal Beceren \\
\hline UK & $\begin{array}{l}\text { Crisis, What Crisis? How Clinical Engineers will Solve the Billion Dollar Healthcare } \\
\text { Funding Gap [53] }\end{array}$ \\
\hline UK, Global & Tropical Health Education Trust (THET) partnerships, A. Worm and Schofield \\
\hline Vietnam & Survey of Personnel Who Are Operating, Repairing and Maintaining Medical Equipment \\
\hline WHO & WHO HT Indicators for MoH, 2009, Joachim Nagel et al [54] \\
\hline WHO & WHO \& International Labor Organization discussions 2015-2017, Adriana Velazquez \\
\hline WHO AMRO & Development and initiatives of medical devices in the Americas, Alexandre Lemgruber \\
\hline WHO EMRO & Strengthening Medical Devices Regulation in the Eastern Mediterranean Region of \\
\hline
\end{tabular}

outside Sao Paulo, Brazil; mobilized their resources to overcome the issue of how to reach indigenous population within the rainforest in Brazil, where over 400,000 people living there with no access to Healthcare. They designed a project to identify the clinical needs for that environment and to successfully organized 38 expeditions providing over 43,000 patient visits and performed over 6000 surgeries, all by volunteers. The clinical engineers were in charge of determining the 
Table 5 List of e-Technology-related submissions organized by region submitting it with authors information and hot links.

\begin{tabular}{|c|c|}
\hline Focus Area. & e-Technology: Title, authors, with active links \\
\hline Brazil & Teleradiology network in Amazonas rainforest, Leonardo Melo, Alessandro Melo \\
\hline Brazil & Telecommunication innovation in mobile health units, Leonardo Melo, Alessandro Melo \\
\hline Brazil & Business intelligence application in health management, O.B. Souto et al \\
\hline Brazil & Geocoding dengue cases for spatial analysis, J. L. S. Lustosa et al \\
\hline Brazil & Integration of the trans-operative information with the patient's electronic record, E. K. \\
\hline Brazil & Dental Chair Unit Clinical Engineering management, G. L.O. da Fonseca, F.S. Rosa, R. Garcia \\
\hline Bulgaria, Greece & Re-engineering a Medical Devices Management Software System: The web approach, \\
\hline China & Mobile control of risk factors of NCDs, Bao Jiali, Zhu Chaoyang, Bao Jiaming, Zheng Xiuxiu \\
\hline China & Mutual recognition research of medical imaging remote intelligent quality control tech- \\
\hline Colombia & Networking from Colombian clinical engineers, Andrea Rocio Garcia Ibarra \\
\hline Colombia & Introducing IHE (Integrating the Healthcare Enterprise) into Colombia \& Latin America, 2015, Vladimir Quintero \\
\hline Georgia & Becoming of Ubiquitous Sensors for Ubiquitous Healthcare, S. Dadunashvili [55] \\
\hline Global & Medical device service procedures mobile application, Jean Ngoie, Kelsea Tomaino \\
\hline Global & Use of CMMS (Computerized Medical equipment Management System) in Low Resource \\
\hline Global & Clinical and ICT (Information and Communication Technologies) Cybersecurity Over- \\
\hline Global & Integrated Health Solutions to deliver value-based Healthcare, Frederic Noel \\
\hline Global & Conquering the leprosy last mile: the role of mobile-phones, Phillip Olla \\
\hline Global & Appropriate CMMS systems - potential for health systems development, Mr. Martin \\
\hline Global & Clinical Engineering, eHealth, and ICT Global Overview, Elliot Sloane \\
\hline Global & Decision Support Systems: an all-around approach to healthcare management, Ernesto \\
\hline Global & Developments in Global Clinical Engineering-Information Technology, Tom Judd, Ricardo \\
\hline Global & Total Cost of Ownership, Elliot Sloane \\
\hline Global & ICT training for Health Technology, Elliot Sloane \\
\hline Global & CE: from Devices to Systems, Roberto Miniati, Ernesto Iadanza, Fabrizio Dori, Italy \\
\hline Global & On-Line HTM Training in Latin America, Tobey Clark et al., 2015 \\
\hline Global & Using Clinical Engineering CMMS to improve care delivery, Bill Gentles \\
\hline Global & Trends on Information Technology and Health Technology, Antonio Hernandez, 2015 \\
\hline Global & Medical Device and ICT Convergence, Elliot Sloane \\
\hline Greece & Web-based medical equipment management system, Nicolas Pallikarakis, Panayiotis Mala- \\
\hline Haiti & $\begin{array}{l}\text { Evidence-based Maternal Child Health Care enabled by Health Technology, Tom Judd, Lee Jacobs, Brian Birch, and Matt } \\
\text { Jansen }\end{array}$ \\
\hline India & Using Near-Patient Data in HTM, Tracy Rausch, Yatin Mehta MD \\
\hline India & Designing MoH HTM IT systems in Developing Countries, Jitendar Sharma, Prabhat Arora \\
\hline India, USA & Using Integrated Clinical Environment (ICE) Data for HTM (India pilot), Tracy Rausch, Tom Judd \\
\hline Italy & SILAM: Integrating Laboratory IS within the Liguria Region EHR, 2014, A. Tagliati et al \\
\hline Japan & Study on Medical Equipment Location Systems that use RFID Technology, Manabu [56] \\
\hline Nigeria & Developing an Appropriate and Affordable Expert System for Medical Diagnosis in De \\
\hline Portugal & End-to-End QoS-Based Admission Control via Virtual Sensor Nodes, Carlos Abreu et al \\
\hline Romania & Development of Wireless Biomedical Data Transmission and Real Time Monitoring System [57] \\
\hline $\begin{array}{l}\text { Saudi Arabia, North Macedonia, } \\
\text { Global }\end{array}$ & Digital hospital 21st century: you certainly can't manage it if you don't understand it, \\
\hline Slovakia & Electronic categorization of medical devices in Slovakia, Dr. Jadud, Ministry of Health \\
\hline South Africa & Medical internet of things and embedded intelligence in healthcare, Abdelbaset Khalaf \\
\hline South Africa & Wireless Body Sensor Network and ECG Android App eHealth. Abdelbaset Khalaf \\
\hline Spain, France & Integrating an EHR Graphical User Interface into Nanoelectronic-Based Biosensor Technology [58] \\
\hline Uruguay & CAMACUA: Low Cost Real Time Risk Alert and Location System for Healthcare Environments [59] \\
\hline USA & Assessing Risk in the Kaiser Permanente CE Program, C Davis-Smith, F Painter, M Baretich [60] \\
\hline USA & Medical Device Cybersecurity, Steve Grimes, HIMSS 2016 \\
\hline USA & Biomedical Device Integration into an Electronic Health Record, Michael Fraai \\
\hline Venezuela, Ecuador & Intelligent System for Identification of patients in Healthcare, Ricardo Silva [61] \\
\hline
\end{tabular}

optimal transportation method and assembly all the medical devices that clinicians needed. They transport it over the challenge of difficult route, to be placed in a highly humid rainforest environment. They assembled, commissioned, and operated the equipment and provided support for clinical services that those patients needed.

At the WHO, in the Health Systems category, Adriana Velasquez have implemented many technology-based patient care programs that have far reach all over the world. Her collaborative efforts perhaps best known through assembling networking of international stake holders during the successful series of Global Forums on Medical Devices. Another successful contribution she achieved has been the development and dissemination of international publication and resources [65] for addressing HT issues such as creating a resource for global atlas of medical devices, global model for regulatory framework, medical device policies, compendium of new and emerging health technologies, human resources 
Table 6 List of Quality and Safety-related submissions organized by region submitting it with authors information and hot links.

\section{Focus Area.}

Australia

Brazil

Brazil

Brazil

Brazil

Brazil

Brazil

Brazil

Brazil

Brazil

China

China

China

China

China

Colombia

Dominican Republic

Germany

Global

Global

Global

Global

Global

Global

Global

Global

Global

Global

Global
Quality \& Safety: Title, authors, with active links

Medical Air Mis-connections, Anne-Louise Smith, Mark McEwen, 2016

An observational study of the high incidence of false and nuisance alarms in an inten

Evaluation of waste disposal inadequate management from health services, Larissa Teix

Improving Health Technology Assessment in Cold Chain by Applying Clinical and Indus

Improving Operational Reliability in Medical Washer Disinfector with the Use of FMEA

Medical devices proactive surveillance - trends and impact from field and enforcement

Structuring the Radiological Report, D.M. Rocha et al

Development of an ubiquitous management platform in air compressors used in pri

The Clinical Engineering in Hospital Accreditation Case Study: Radiology Clinic, R.A.M.

Clinical Engineering/Health Technology regulation, evaluation \& training to improve

A Hospital-based Dynamic Warning System Medical Consumables Regarding Adverse

Case Study and Management Improvement of Medical Devices, Jing-ying Gao, Lei Wei,

Survey and analysis of current state of ventilator alarms in ICU, Lin, Zheng Kun

Shanghai Region Medical Equipment Quality and Safety, Li Bin

Design of a Web-based Medical Equipment Management System for CE, 2015, Liu [62]

MoH Health Technology Management Regulations, Andrea Garcia-Ibarra

Medical - Surgical Vacuum and Anesthetic Residue Extraction Policy in the Dominican

Technological Surveillance and Integrity Monitoring of Infusion Systems, D. Grosse-Wentrup [63]

A pneumonia prevention system, Peter Young; Maryanne Mariyaselam

Global Professional Credentialing Project, Yadin David, Mario Medvedec, Jim Wear

Adoption of medical-technologies in infrastructure-poor environments, Gisela Abbam,

Hospital Integrated Networks Risk Management Issues and Recommendations, Yadin

Skill development for growth in emerging markets, Gisela Abbam, Marut Setia

Clinical Engineering Risk Management, Frank Painter

CE Certification globally to improve care delivery, Jim Wear, Mario Medvedec

Human Factors Engineering book - global resource, Tony Easty et al

Global training partnerships, Shauna Mullally

Promoting the Image of Biomedical Engineers and Improving Safety, Michael Cheng

Managing the medical equipment lifecycle resource, THET, Anna Worm 
Table 6 (continued)

\begin{tabular}{|c|c|}
\hline Focus Area. & Quality \& Safety: Title, authors, with active links \\
\hline Global & $\begin{array}{l}\text { Medical Equipment Maintenance book, 2013, Binseng } \\
\text { Wang }\end{array}$ \\
\hline Global & $\begin{array}{l}\text { Profile of Biomedical Engineering Education in Latin } \\
\text { America, SJ Calil et al }\end{array}$ \\
\hline Global & Preventable Adverse Events: How to? Yadin David \\
\hline Global & $\begin{array}{l}\text { Medical Device Risk Management from a Human } \\
\text { Factors Perspective, Tony Easty }\end{array}$ \\
\hline Global & $\begin{array}{l}\text { Medical Devices Vigilance and the European Union } \\
\text { Regulations, Nicolas Pallikarakis }\end{array}$ \\
\hline Italy & $\begin{array}{l}\text { A new digital era of Clinical and Biomedical process, } \\
\text { Giulia and Stefano Marchesi }\end{array}$ \\
\hline Italy, Egypt & $\begin{array}{l}\text { A New Approach for Preventive Maintenance } \\
\text { Prioritization of Medical Equipment, } \mathrm{Ne}\end{array}$ \\
\hline Japan & $\begin{array}{l}\text { The role of policymakers for health technologies, Dr. } \\
\text { Masato Mugitani }\end{array}$ \\
\hline Jordan & $\begin{array}{l}\text { Implementation of Six Sigma on Case Study at the } \\
\text { Directorate of BME in the Jordanian Ministry of } \\
\text { Health [64] }\end{array}$ \\
\hline Kenya & $\begin{array}{l}\text { Roadmap to validation and verification of Intravenous } \\
\text { Devices in Kenya, Bintiomar Tsala, }\end{array}$ \\
\hline Kuwait & $\begin{array}{l}\text { Safe care: An initiative for regulations in Kuwait, } \\
\text { WHO 2GFMD, 2013, Ms. Hanan Al-awa }\end{array}$ \\
\hline Mexico & Impact of State CE Directorate, Ignacio Macias, 2016 \\
\hline Mozambique, Portugal & $\begin{array}{l}\text { Training program in Central Hospital of Maputo } \\
\text { (2011-2016), Mario Forjaz Secca }\end{array}$ \\
\hline Papua New Guinea & $\begin{array}{l}\text { Improving pediatric and neonatal care in rural district } \\
\text { hospitals in the highlands of Papua New Guinea: a } \\
\text { Quality Improvement approach, M. Saavu, Trevor } \\
\text { Duke, Sens Matai }\end{array}$ \\
\hline Samoa, Fiji & $\begin{array}{l}\text { User Care of Medical Equipment, Nehal Kapadia, } \\
\text { Sunema Talapusi }\end{array}$ \\
\hline Saudi Arabia & $\begin{array}{l}\text { Unifying Efforts against Counterfeiting Medical } \\
\text { Devices, Nazeeh Alothmany }\end{array}$ \\
\hline Taiwan & $\begin{array}{l}\text { Actions of medical device post-market surveillance, } \\
\text { KP Lin, Y-T Hung, Shiu- Huei Yeh }\end{array}$ \\
\hline USA & $\begin{array}{l}\text { Application of Quality, Risk \& Asset Management } \\
\text { Principles to Clinical Engineering, Bin }\end{array}$ \\
\hline $\begin{array}{l}\text { Cape Verde, Senegal, The Gambia, Guinea Bissau, } \\
\text { Guinea, Sierra Leone, Li- beria, Mali, Ivory Coast, } \\
\text { Ghana, Togo, Benin, Bur- kina Faso, Nigeria, Niger }\end{array}$ & $\begin{array}{l}\text { The West African Health Organization, Biomedical } \\
\text { Engineering Curriculum, Bobo-Dioul }\end{array}$ \\
\hline
\end{tabular}

for medical devices, and the 2017 WHO list of priority medical devices for cancer management to name a few. The above examples and the rest of the evidence provided in this manuscript support the notion that healthcare services all over the world are more accessible, appropriate, efficient and with increasing quality because of CE involvement.

\section{Conclusions}

HT is vital to health and the dependence of health, rehabilitation, and wellness programs that rely on HT for the delivery of their services has never been greater. Beyond the ongoing healthcare burdens of population growth, political and economic instability, disease management, disasters, the refugee crisis, accidents, and terror attacks, world healthcare technological systems are facing enormous challenges to be innovative and optimally managed. The transition into health programs for the 21 st century requires the employment of trained competent $\mathrm{CE}$ professionals. Disease prevention, treatment, and rehabilitation is more efficient and effective when health services are provided with appropriate tools. Along with World Health Organization (WHO) [66], the International 
Federation for Medical and Biological Engineering (IFMBE) Clinical Engineering Division (CED) recognizes and emphasizes how important the use of appropriate, integrated, and safe health technologies (HT) is to successful outcomes for every healthcare delivery systems. In the May 2016 HT resource document was delivered to the World Health Assembly (WHA), with a recommendation that: Health technologies must be managed to ensure full clinical benefit and expected financial return on investment.

It is critical, therefore, that with limited availability of resources, HT must be professionally managed and its creation and deployment over its life-cycle be appropriately guided. This paper describes the extensive study of published data on the vast contributions by CE that positively impact patient outcomes. This finding of this study shows that every region of the world including lowresource regions face a challenge of improving health services while facing varied levels of infrastructure and human resources capacity challenges. CEs play vital roles in all stages of healthcare technology life-cycle management. From creation to planning, and from commissioning to utilization and integration; technology-based systems must and can be managed for optimal performance. In each of the technology life-cycle stages the requirement for trained and competent CE input makes critical difference as evidence show in the analyzed data reviewed above. It is our hope that government agencies and other interested parties will have better understanding of CEs role and thus will support their inclusion in the healthcare team of professionals.

The identified and qualified 400 case studies shown in this manuscript support the need to expand the reach of $\mathrm{CE}$ community in order to provide competent guide to management of healthcare technologies around the world. Case studies - grouped in 6 categories - can assist to formulate national strategies and plans on how to improve the creation and deployment of HT while improving quality of care and efficient use of scares funding. In several countries, case studies demonstrated, this has best been achieved by developing a HT unit at the level of Ministry of Health that engages the CE community. These studies provide evidence that HT is beneficial; however, at times, deployment of such complex systems when it is not effectively guided and managed may not realize intended outcomes for optimal impact.

The 2007 WHO WHA Resolution 60.29 urges Member States to create national HT management plans in collaboration with clinical and biomedical engineers. WHO further clarified the definition of these personnel in 2017-2018 as part of a global survey [67] in coordination with IFMBE/CED.
"Trained and qualified biomedical engineering professionals are required to design, evaluate, regulate, maintain and manage medical devices, and train on their safe use in health systems around the world.5" These occupations have various names in different countries like clinical engineers, medical engineers, ... and related professionals and technicians."

We encourage the dissemination of survey tools as describe here to better understand the need for and monitoring of progress towards safe, appropriate and optimal quality care outcomes.

The authors express gratitude for the intense work invested by members of the project task force and for Kallirroi Stavrianou for creating and validating all of evidence links on the tables above.

\section{Compliance with ethical standards}

Conflict of interest The authors declare that they have no conflict of interest.

Ethical approval This article does not contain any studies with human participants or animals performed by any of the authors.

Informed consent Informed consent was not obtained since there were individual participants included in the study.

\section{References}

1. Taylor RM, Alper J. Using technology to advance Global Health, proceedings of a workshop, forum on public - private partnerships for Global Health and safety. Washington, DC: The National Academies Press; 2018.

2. Kairy D, Lehoux P, Vincent C, Visintin M. A Systematic Review of Clinical Outcomes, Clinical Process, Healthcare Utilization and Costs Associated with Telerehabilitation. Journal Disability and Rehabilitation. 2009;31(6):427-47.

3. Judd T, David Y, Making a Difference - Global Health Technology Success Stories: Overview of over 400 submissions from 125 Countries, Global Clinical Engineering Journal, Vol. 1, Issue 1, 2018. https://www.globalce.org/index.php/GlobalCE/article/view/ 43 (last visited Feb. 1, 2019).

4. Health Technology Strategy 1.0, Health Technology Assessment Task Group, Advisory Committee on Information and Emerging Technologies, Canada, 2004. https://www.cadth.ca/media/policy forum_section/1_health_tech_strategy_1.0_nov-2004_e.pdf (last visited Feb. 5, 2019).

5. Fiedler, B., Managing Medical Devices within a Regulatory Framework, Elsevier, 2016. (https://www.elsevier.com/books/ managing-medical-devices-within-a-regulatory-framework/fiedler/ 978-0-12-804179-6). (last visited January 2, 2019).

6. Ebola Virus Disease, Infection Prevention and Control Recommendations for Hospitalized Patients Under Investigation (PUIs) for Ebola Virus Disease (EVD) in U.S. Hospitals, Center for Disease Control and Prevention (CDC), 2014. https://www.cdc. gov/vhf/ebola/clinicians/evd/infection-control.html (last visited Feb. 1, 2019).

7. Borras, C. Defining the medical imaging requirements for a rural health center, health technology task group (HTTG) of the 
International Union of Physical and Engineering Sciences in medicine (IUPESM), Springer, 2017.

8. Judd T, Hernandez A, Gentles W, Calil S, Clinical Engineering/ Health Technology Management 2015 Global Update, Global Clinical Engineering Journal, Vol. 0, No. 1, pages 4-14, May 2018. https://globalce.org/index.php/GlobalCE/article/view/ 21 (last visited Feb. 1, 2019).

9. David Y, Invitation Letter for the Global CE Summit, Advisory Group. 2015, http://global.icehtmc.com/aboutus/aboutus_letter (last visited Jan. 5, 2019).

10. International Federation of Medical and Biological Engineering http://ifmbe.org/ (last visited January 15, 2019).

11. First ICEHTMC, Hangzhou, China, October 21-22, 2015, https:// portal.engineersaustralia.org.au/sites/default/files/events/2015/ ICEHTMC2015_Hangzhou_-China_-_October.pdf (last visited Feb. 2, 2019).

12. WHO - Third WHO Global Forum on Medical Devices, Medical devices, https://www.who.int/medical_devices/global_forum/3rd gfmd/en/ (last visited Feb. 5, 2019).

13. Medical \& Biological Engineering \& Computing Yadin David; Thomas Judd https://link.springer.com/journal/11517, (last visited Feb. 5, 2019).

14. Health Technologies Resource - Global Clinical Engineering Summit Success Stories, 2016, http://global.icehtmc.com/ publication/healthteachnology (last visited Feb, 3, 2019).

15. Sarmiento CA, Hernández AM, Serna LY, Model Fitting and Simulation of the Respiratory Control System under Incremental Exercise and Altitude in Healthy Subjects. In: Torres I., Bustamante J., Sierra D. (eds) VII Latin American Congress on Biomedical Engineering CLAIB 2016, Bucaramanga, Santander, Colombia, October 26th -28th, 2016. IFMBE proceedings, vol 60. Springer, Singapore, 2017.

16. Otálvaro JD, Zuluaga AF, Hernández AM, Modeling and simulation of ciprofloxacin pharmacokinetics: electric circuits approach. In: Torres I., Bustamante J., Sierra D. (eds) VII Latin American Congress on Biomedical Engineering CLAIB 2016, Bucaramanga, Santander, Colombia, October 26th -28th, 2016. IFMBE proceedings, vol 60. Springer, Singapore, 2017.

17. Castaño FA, Hernández AM, Autoregressive Models of Electrocardiographic Signal Contaminated with Motion Artifacts: Benchmark for Biomedical Signal Processing Studies. In: Torres I., Bustamante J., Sierra D. (eds) VII Latin American Congress on Biomedical Engineering CLAIB 2016, Bucaramanga, Santander, Colombia, October 26th -28th, 2016. IFMBE proceedings, vol 60. Springer, Singapore, 2017.

18. Cárdenas AM, Uribe J, Hernández AM, Parametric Modeling of Kinetic-Kinematic Polycentric Mechanical Knee. In: Torres I., Bustamante J., Sierra D. (eds) VII Latin American Congress on Biomedical Engineering CLAIB 2016, Bucaramanga, Santander, Colombia, October 26th -28th, 2016. IFMBE proceedings, vol 60. Springer, Singapore, 2017.

19. Castaño FA, Hernández AM. Motion Artifacts Recognition in Electrocardiographic Signals through Artificial Neural Networks and Support Vector Machines for Personalized Health Monitoring. In: Torres I., Bustamante J., Sierra D. (eds) VII Latin American Congress on Biomedical Engineering CLAIB 2016, Bucaramanga, Santander, Colombia, October 26th -28th, 2016. IFMBE proceedings, vol 60. Springer, Singapore, 2017.

20. Salazar Sánchez MB, Hernández AM, Botero Ospina AF, Cortés Daza CC, Learning Tool for Mechanical Ventilation during Spontaneous Breathing Test on Patients Intoxicated with Pesticides. In: Torres I., Bustamante J., Sierra D. (eds) VII Latin American Congress on Biomedical Engineering CLAIB 2016, Bucaramanga, Santander, Colombia, October 26th -28th, 2016. IFMBE proceedings, vol 60. Springer, Singapore, 2017.
21. Valderrama-Hincapié SE, Hernández AM, Sánchez F, RoldánVasco S, López-Ríos AL, Hutchison WD, Optimization of spectral analysis of electrophysiological recordings of the subthalamic nucleus in Parkinson's disease: A retrospective study. In: Torres I., Bustamante J., Sierra D. (eds) VII Latin American Congress on Biomedical Engineering CLAIB 2016, Bucaramanga, Santander, Colombia, October 26th -28th, 2016. IFMBE proceedings, vol 60. Springer, Singapore, 2017.

22. Ruiz AE, Aristizábal JK, Three Dimensional Reconstruction and Airflow Simulation in a Realistic Model of the Human Respiratory Airways. In: Torres I., Bustamante J., Sierra D. (eds) VII Latin American Congress on Biomedical Engineering CLAIB 2016, Bucaramanga, Santander, Colombia, October 26th -28th, 2016. IFMBE proceedings, vol 60. Springer, Singapore, 2017.

23. Mercado MM, Hernandez AM, Cruz JC, Permanent Magnets to Enable Highly-Targeted Drug Delivery Applications: A Computational and Experimental Study. In: Torres I., Bustamante J., Sierra D. (eds) VII Latin American Congress on Biomedical Engineering CLAIB 2016, Bucaramanga, Santander, Colombia, October 26th -28th, 2016. IFMBE proceedings, vol 60. Springer, Singapore, 2017.

24. Carmona J, Suarez J, Ochoa J, Brain Functional Connectivity in Parkinson's disease - EEG resting analysis. In: Torres I., Bustamante J., Sierra D. (eds) VII Latin American Congress on Biomedical Engineering CLAIB 2016, Bucaramanga, Santander, Colombia, October 26th -28th, 2016. IFMBE proceedings, vol 60. Springer, Singapore, 2017.

25. Zulj S et al, Supporting Diabetic Patients with a Remote Patient Monitoring Systems. In: Torres I., Bustamante J., Sierra D. (eds) VII Latin American Congress on Biomedical Engineering CLAIB 2016, Bucaramanga, Santander, Colombia, October 26th -28th, 2016. IFMBE proceedings, vol 60. Springer, Singapore, 2017.

26. Canali $\mathrm{C}$ et al, Impedance-based monitoring for tissue engineering applications. In: Simini F., Bertemes-Filho P. (eds) II Latin American conference on bioimpedance. IFMBE proceedings, vol 54. Springer, Singapore, 2016.

27. Ciani O, Federici C, Tarricone R, Current and Future Trends in the HTA of Medical Devices. In: Kyriacou E., Christofides S., Pattichis C. (eds) XIV Mediterranean Conference on Medical and Biological Engineering and Computing 2016. IFMBE proceedings, vol 57. Springer, Cham, 2016.

28. Giansanti D, Maccioni G, Pochini M, Giovagnoli MR, HTA of a Large Tablet System in Digital Pathology. In: Kyriacou E., Christofides S., Pattichis C. (eds) XIV Mediterranean Conference on Medical and Biological Engineering and Computing 2016. IFMBE proceedings, vol 57. Springer, Cham, 2016.

29. Li J, Zhan QY, Wang C. Survey of prolonged mechanical ventilation in intensive care units in mainland China. Respir Care. 2016;61(9):1224-31. https://doi.org/10.4187/respcare.04295.

30. Sebesi SB, Groza HL, Mândru D, Telemonitoring systems and Technologies for Independent Life of elderly. In: Vlad S., Roman $\mathrm{N}$. (eds) international conference on advancements of medicine and health care through technology; 12th - 15th October 2016, ClujNapoca, Romania. IFMBE proceedings, vol 59. Springer, Cham, 2017.

31. Lehocki F, Bacigal T, Telemedicine and mHealth System for Complex Management in T1DM and T2DM Patients: Results of 6 Months Study. In: Kyriacou E., Christofides S., Pattichis C. (eds) XIV Mediterranean Conference on Medical and Biological Engineering and Computing 2016. IFMBE proceedings, vol 57. Springer, Cham, 2016.

32. Gurbeta L, Alic B, Dzemic Z, Badnjevic A, Testing of dialysis machines in healthcare institutions in Bosnia and Herzegovina. In: Eskola H., Väisänen O., Viik J., Hyttinen J. (eds) EMBEC \& NBC 2017. EMBEC 2017, NBC 2017. IFMBE proceedings, vol 65. Springer, Singapore, 2018. 
33. Santos FA, Margotti AE, Ferreira FB, Garcia R, Health Technology Assessment Applied to Health Technology Management through Clinical Engineering. In: Roa Romero L. (eds) XIII Mediterranean Conference on Medical and Biological Engineering and Computing 2013. IFMBE proceedings, vol 41. Springer, Cham, 2014.

34. Cruz AM, Rodriguez Dueñas WR, Estimation of the optimal maintenance frequency of medical devices: A Monte Carlo simulation approach. In: Torres I., Bustamante J., Sierra D. (eds) VII Latin American Congress on Biomedical Engineering CLAIB 2016, Bucaramanga, Santander, Colombia, October 26th -28th, 2016. IFMBE proceedings, vol 60. Springer, Singapore, 2017.

35. Quiroga Torres DA, Presiga AM, Flórez Luna N, Cruz AM, Teaching maintenance of medical devices in simulation centers: a pilot study. In: Torres I., Bustamante J., Sierra D. (eds) VII Latin American Congress on Biomedical Engineering CLAIB 2016, Bucaramanga, Santander, Colombia, October 26th -28th, 2016. IFMBE proceedings, vol 60. Springer, Singapore, 2017.

36. Iadanza E, Worm A, Clinical Engineering Online Courses for Africa. In: Eskola H., Väisänen O., Viik J., Hyttinen J. (eds) EMBEC \& NBC 2017. EMBEC 2017, NBC 2017. IFMBE proceedings, vol 65. Springer, Singapore, 2018.

37. Bibbo D, Schmid M, Scorza A, Sciuto SA, Conforto S, A Novel Approach to Improve the Technical Maintenance of Biomedical Equipment. In: Kyriacou E., Christofides S., Pattichis C. (eds) XIV Mediterranean Conference on Medical and Biological Engineering and Computing 2016. IFMBE proceedings, vol 57. Springer, Cham, 2016.

38. Chen MF et al, The Benefit of in-Hospital Clinical Engineer Services for Medical Devices Maintenance. In: Kyriacou E., Christofides S., Pattichis C. (eds) XIV Mediterranean Conference on Medical and Biological Engineering and Computing 2016. IFMBE proceedings, vol 57. Springer, Cham, 2016.

39. Mullally S, Bbuku T, Musonda G, Medical equipment maintenance personnel and training in Zambia. In: long M. (eds) world congress on medical physics and biomedical engineering may 26-31, 2012, Beijing, China. IFMBE proceedings, vol 39. Springer, Berlin, Heidelberg, 2013.

40. Worm AME, The Potential Power of sub-Saharan Africa Professional Associations for Biomedical/Clinical Engineering Professionals. In: Kyriacou E., Christofides S., Pattichis C. (eds) XIV Mediterranean Conference on Medical and Biological Engineering and Computing 2016. IFMBE proceedings, vol 57. Springer, Cham, 2016.

41. Lin KP, Chen MF, Tsai CL, Tsai K, Status of Biomedical Engineering Education in the Asia Pacific. In: Kyriacou E., Christofides S., Pattichis C. (eds) XIV Mediterranean Conference on Medical and Biological Engineering and Computing 2016. IFMBE proceedings, vol 57. Springer, Cham, 2016.

42. Fagundes VO, Zaniboni R, Garcia R, Cost Estimate Methodology in procurement processes of ME. In: Torres I., Bustamante J., Sierra D. (eds) VII Latin American Congress on Biomedical Engineering CLAIB 2016, Bucaramanga, Santander, Colombia, October 26th 28th, 2016. IFMBE proceedings, vol 60. Springer, Singapore, 2017.

43. Guerrero JC, García JH, Hernández AM, Study of Medical Device Purchasing Cycles through Temporal Series Analysis. In: Torres I., Bustamante J., Sierra D. (eds) VII Latin American Congress on Biomedical Engineering CLAIB 2016, Bucaramanga, Santander, Colombia, October 26th -28th, 2016. IFMBE proceedings, vol 60. Springer, Singapore, 2017.

44. Madroñal Ortiz M, Galeano Upegui B, Escobar Mora N, Cruz Parra $\mathrm{L}$, Rios Cuartas I, Identifying the needs in the integration of disciplines in the hospital infrastructure management in Colombia. In: Torres I., Bustamante J., Sierra D. (eds) VII Latin American Congress on Biomedical Engineering CLAIB 2016,
Bucaramanga, Santander, Colombia, October 26th -28th, 2016. IFMBE proceedings, vol 60. Springer, Singapore, 2017.

45. Chaveco Salabarria Y, Rubio Romero JC, Guerra Bretaña RM, Trading barriers in the medical devices industry. Are these barriers hindering the development of this sector in Cuba? In: Torres I., Bustamante J., Sierra D. (eds) VII Latin American Congress on Biomedical Engineering CLAIB 2016, Bucaramanga, Santander, Colombia, October 26th -28 th, 2016. IFMBE proceedings, vol 60. Springer, Singapore, 2017.

46. Kubátová I, Matloňová V, Hospital Based HTA - Implementation for the Czech Republic. In: Kyriacou E., Christofides S., Pattichis C. (eds) XIV Mediterranean Conference on Medical and Biological Engineering and Computing 2016. IFMBE proceedings, vol 57. Springer, Cham, 2016.

47. Iadanza E. IFMBE/Clinical Engineering Division projects for the advancement of the profession of Clinical Engineering. In: Eskola H., Väisänen O., Viik J., Hyttinen J. (eds) EMBEC \& NBC 2017. EMBEC 2017, NBC 2017. IFMBE proceedings, vol 65. Springer, Singapore, 2018.

48. Worm A, Linnenbank AC, The potential role of IFMBE in improving the state of medical equipment in developing countries. In: Jaffray D. (eds) world congress on medical physics and biomedical engineering, June 7-12, 2015, Toronto, Canada. IFMBE proceedings, vol 51. Springer, Cham, 2015.

49. Luschi A, Caltagirone L, Mondovecchio C, Miniati R, Iadanza E, Assessing the Impact of a CIS/PACS Technology for a Cardiology Department Using QFD Methodology. In: Kyriacou E., Christofides S., Pattichis C. (eds) XIV Mediterranean Conference on Medical and Biological Engineering and Computing 2016. IFMBE proceedings, vol 57. Springer, Cham, 2016.

50. Díaz MZ, Koch AP, The Status of BME Programs in Latin America. In: Kyriacou E., Christofides S., Pattichis C. (eds) XIV Mediterranean Conference on Medical and Biological Engineering and Computing 2016. IFMBE proceedings, vol 57. Springer, Cham, 2016.

51. Sontea V, Morgoci S, Turcanu G, Pislaru C, Medical devices management strategy in the Republic of Moldova. In: Sontea V., Tiginyanu I. (eds) 3rd international conference on nanotechnologies and biomedical engineering. IFMBE proceedings, vol 55. Springer, Singapore, 2016.

52. Vilcahuaman L, Cordova M, Kalafatovich J, Rivas R, A Comprehensive System for Healthcare Technology Management HTM. In: Torres I., Bustamante J., Sierra D. (eds) VII Latin American Congress on Biomedical Engineering CLAIB 2016, Bucaramanga, Santander, Colombia, October 26th -28th, 2016. IFMBE proceedings, vol 60. Springer, Singapore, 2017.

53. Clark DJ, Crisis, What Crisis? How Clinical Engineers Will Solve the Billion Dollar Healthcare Funding Gap. In: Kyriacou E., Christofides S., Pattichis C. (eds) XIV Mediterranean Conference on Medical and Biological Engineering and Computing 2016. IFMBE proceedings, vol 57. Springer, Cham, 2016.

54. Nagel JH, Nagel M, Indicators for Evaluating and Measuring the Impact of Healthcare Infrastructure and Technology Management on Investments, Service Delivery and Quality of Care. In: Dössel O., Schlegel W.C. (eds) World Congress on Medical Physics and Biomedical Engineering, September 7-12, 2009, Munich, Germany. IFMBE Proceedings, vol 25/12. Springer, Berlin, Heidelberg, 2009

55. Dadunashvili S, Becoming of ubiquitous sensors for ubiquitous healthcare. In: Jaffray D. (eds) world congress on medical physics and biomedical engineering, June 7-12, 2015, Toronto, Canada. IFMBE proceedings, vol 51. Springer, Cham, 2015.

56. Kawabe M, Miwa Y, Kano T, Study on medical equipment location systems that use RFID technology. In: Jaffray D. (eds) world congress on medical physics and biomedical engineering, June 7-12, 
2015, Toronto, Canada. IFMBE proceedings, vol 51. Springer, Cham, 2015.

57. Fort CM, Gergely S, Berar AO, Development of wireless biomedical data transmission and real time monitoring system. In: Vlad S., Roman N. (eds) international conference on advancements of medicine and health care through technology; 12th - 15th October 2016, Cluj-Napoca, Romania. IFMBE proceedings, vol 59. Springer, Cham, 2017.

58. Quintero AM et al. Integrating an Electronic Health Record Graphical User Interface into Nanoelectronic-Based Biosensor Technology. In: Roa Romero L. (eds) XIII Mediterranean Conference on Medical and Biological Engineering and Computing 2013. IFMBE proceedings, vol 41. Springer, Cham, 2014.

59. Decia I et al, CAMACUA: Low Cost Real Time Risk Alert and Location System for Healthcare Environments. In: Torres I., Bustamante J., Sierra D. (eds) VII Latin American Congress on Biomedical Engineering CLAIB 2016, Bucaramanga, Santander, Colombia, October 26th -28th, 2016. IFMBE proceedings, vol 60. Springer, Singapore, 2017.

60. Davis-Smith CE, Painter FR, Baretich MF. Assessing risk in the Kaiser Permanente clinical technology program. Biomedical Instrumentation \& Technology: Risk: How Do You Manage It Effectively? 2015;49(s1):60-4.

61. Silva $\mathrm{R}$ et al., Intelligent System for Identification of patients in Healthcare. IFMBE Proceedings 51. 10.1007/978-3-319-19387$8 \_353$

62. Shenglin L, Qiang Z, Hanxi W, Xutian Z, Guohong W, Design of a web-based medical equipment management system for clinical engineering. In: Long M. (eds) world congress on medical physics and biomedical engineering may 26-31, 2012, Beijing, China. IFMBE proceedings, vol 39. Springer, Berlin, Heidelberg, 2013.

63. Grosse-Wentrup D, Hoelscher UM, Technological surveillance and integrity monitoring of infusion systems. In: Jaffray D. (eds) world congress on medical physics and biomedical engineering, June 712, 2015, Toronto, Canada. IFMBE proceedings, vol 51. Springer, Cham, 2015.
64. Al-Bashir A, Al-Tawarah A. Implementation of Six Sigma on Corrective Maintenance Case Study at the Directorate of Biomedical Engineering in the Jordanian Ministry of Health. Proceedings of the 2012 International conference on industrial engineering and operations management Istanbul, Turkey, 2012.

65. WHO Publications on Medical Devices, Medical Devices, https:// www.who.int/medical_devices/publications/en/, (last visited Feb. 8, 2019).

66. Biomedical Engineering Global Resources, WHO Medical Devices, 2017, https://www.who.int/medical_devices/support/en/ (last visited Feb. 6, 2019).

67. Human Resources for Medical Devices, the Role of Biomedical Engineers, WHO, Medical Devices, https://www.who.int/ medical_devices/publications/hr_med_dev_bio-engineers/en/ (Last visited Feb. 5, 2019).

68. Jamal A, McKenzie K, Clark M. The Impact of Health Information Technology on the Quality of Medical and Health Care: A Systematic Review. Health Information Management Journal. 2009;38(3):26-37.

69. Jacobzone S, Oxley H. Healthcare Expenditure A Future in Question, The OECD Observer No. 229, pages 15-17, Paris, France, 2001

70. Global Clinical Engineering Summit at the First International Clinical Engineering and Health Technology Management Congress https://www.bing.com/search?q=icehtmc+hangzhou+ $2015+\&$ for m $=$ E D G H P T \& $\mathrm{q} \mathrm{s}=$ H S \& c v i d = 25 eef 19 ebda 243 d cbd 345 bea 5493 d 28 a \& refig $=$ $228 \mathrm{dd} 87718 \mathrm{~b} 544 \mathrm{a} 99098 \mathrm{c} 75 \mathrm{f} 7 \mathrm{cf9} 1781 \& \mathrm{cc}=\mathrm{US} \&$ setlang=enUS\&plvar=0\&PC=DCTS (last visited January 15,2019 ).

Publisher's note Springer Nature remains neutral with regard to jurisdictional claims in published maps and institutional affiliations. 